\title{
CHRISTIAN-MUSLIM MORALITY AND FUNDAMENTALISM: The Ethical Perspectives of Karl Barth, and Hasan al-Banna
}

\author{
Izak Yohan Matriks Lattu \\ Departemen Teologi dan Sosiologi Agama \\ Universitas Kristen Satya Wacana, Salatiga - Indonesia \\ e-mail: izaklattu@gmail.com; lattu@staff.uksw.edu
}

\begin{abstract}
The article explores Karl Barth and Hasan al-Banna ideas on ethics as the guidance for communal life. Barth emphasizes the command of God as the fundamental theology of Christian values. The prominent German theologian functions as the pivotal scholar in Christian evangelical stream. While al-Banna underlines the centrality of Islamic Sharia to reform Muslim life under colonial circumstances. As it is for Barth in the Christian side, Banna thought influences fundamentalist groups in many Muslim majority countries such as Egypt, Indonesia and many more. Using a comparative study method, the article concludes that both scholars focus on how scriptures function as the fundamental value for human understanding of social and spiritual life. Although they shared similar issues, Barth, on the one hand, focuses more on how Christianity resist liberalism through the complete acceptance of the holy spirit role in Christian life. Banna, on the other hand, pay more attention to the application of Islamic values as the weapon to fight colonialism.
\end{abstract}

\begin{abstract}
Abstrak: Artikel ini membahas pemikiran etika sebagai kerangka kehidupan masyarakat dari teolog Kristen Jerman, Karl Barth, dan pemikir Islam Mesir, Hasan al-Banna. Barth menekankan peranan perintah Tuhan sebagai teologi fundamental dalam kehidupan kekristenan. Pemikiran Karl Barth mempengaruhi banyak teolog fundamentalis Kristen Injili di berbagai belahan dunia. Sedangkan al-Banna menekankan sentralitas syari'ah Islam untuk mereformasi kehidupan kaum Muslim dalam konteks menghadapi kolonialisasi. Sebagaimana Barth yang sangat berpengaruh pada pemikiran Kristen, pemikiran al-Banna sangat memengaruhi banyak pemikir fundamentalis pada negara-negara dengan penduduk Muslim mayoritas seperti Mesir dan Indonesia. Dengan menggunakan kerangka studi perbandingan, artikel ini berkesimpulan bahwa kedua pemikir menekankan pentingnya firman Allah dalam Kitab Suci sebagai tuntunan etika kehidupan masyarakat beragama, Islam dan Kristen. Meskipun sama-sama menekankan peran etika dalam Kitab Suci, Barth lebih memberikan perhatian pada bagaimana komunitas Kristen melawan liberalism dan mengembalikan peran spiritualitas Kristen. Sedangkan al-Banna menggarisbawahi peran syari'ah Islam sebagai senjata perlawanan terhadap koloniliasme.
\end{abstract}

Keywords: morality and fundamentalism; ethical perspective; Karl Barth; Hasan al-Banna 


\section{A. Introduction}

Karl Barth and Hasan al-Banna are among the biggest names in the Christian and Muslim theological traditions. ${ }^{1}$ Therefore, many scholars have already explored Barth and Banna ideas on morality, religion, and politics. ${ }^{2}$ However, existing studies did not compare Barth and Banna ideas of morality and religious fundamentalism. This article is aiming to explore the similarities and differences of Barth and Banna concepts of morality and fundamentalism. Barth's fourth (IV) volumes of the Church Dogmatics that published from 1932 to 1967 functions as the "holy book" of Protestant theologians and seminarians for about a century. Barth' Church Dogmatics I investigate the Doctrine of the Word of God, Church Dogmatics II covers the Doctrine of God, Church Dogmatics III explores the Doctrine of Creation, Church Dogmatics IV provides the explanation of the Doctrine of Reconciliation. His scholarly works influence Christian theology in both the Catholic and Protestant traditions, Protestant the most. No one may doubt that Protestant theological books and dissertations that were written between the nineteen forty's and nineteen eighty's would take Barth's thought into serious account. Meanwhile, Hasan al-Banna is an important figure among fundamentalist Muslim groups. As the founder of Ikhwān al-Muslimīn or Muslim Brotherhood, Banna's concept of religious morality has driven the wave of change in some Muslim-majority countries such as Egypt, Malaysia, Indonesia

1John Webster, Barth's Earlier Theology (New York: T\&T Clark, 2005); Alexander Massmann, Citizenship in Heaven and on Earth: Karl Barth's Ethics (Meneapolis: Fortress, 2015); Jon Coutts, $A$ Shared Mercy: Karl Barth on Forgiveness and the Church (Grove: IVP Academic, 2016); Tariq Ramadan, Aux Sources Du Renoveau Musulman: D' al-Afghani a Hasan al-Banna Un Siecle de Reformisme Islamique (Religions En Dialogue) (Paris: Centurion, 1998); Roxanne L. Euben and Muhammad Qasim Zaman, eds., Princeton Readings in Islamic Thought: Texts and Contexts from alBanna to Bin Laden (Princeton: Princeton University Press, 2009).

${ }^{2}$ Khalil al-Anani, "The Power of the Jama'a: The Role of Hasan al-Banna in Constructing the Muslim Brotherhood's Collective Identity," Sociology of Islam 1, no. 1-2 (2013): 41-63, https:// doi.org/10.1163/22131418-00101003; Youssef H. Aboul-Enein, "Al-Ikhwan Al-Muslimeen: The Muslim Brotherhood," Military Review 83, no. 4 (2003): 26-31, https://www.questia.com/ library/journal/1G1-109268859/al-ikhwan-al-muslimeen-the-muslim-brotherhood; Ana Soage, "Hasan al-Bannā and Sayyid Quțb: Continuity or Rupture?," The Muslim World 99, no. 2 (2009): 294311, https://doi.org/10.1111/j.1478-1913.2009.01270.x; Carrie R Wickham, The Muslim Brotherhood: Evolution of an Islamist Movement (Princeton: Princeton University Press, 2013); John Webster, ed., The Cambridge Companion to Karl Barth (Cambridge: Cambridge University Press, 2000); William Werpehowski, Karl Barth and Christian Ethics: Living in Truth (Burlington: Ashgate, 2014); Carys Moseley, Nations and Nationalism in the Theology of Karl Barth (Oxford: Oxford University Press, 2013). 
and many more. Even though his figure has been situated alongside fundamentalist Islamic scholars such as Mawdudi, Rida, Wahhab, and his successor Seyyed Qutub, Banna's contribution to the shape of Islam and the relationship between religion and the world today is undeniable.

The main reasons why I bring Barth and Banna into this work: first, both of them lived in the same era. Barth was born in eighteen eighty-six and died in nineteen sixty-eight, whereas Banna was born in nineteen hundred and eight and killed by the Egyptian government in nineteen fourty-nine. Both of them worked under circumstances where the rise of nationalism and anti-colonialism flourished in the heart of colonized countries. While Banna came from the colonized country with the moral and ethical perspective which used religion as the weapon of rebellion, Barth's ethical theology is from the viewpoint of a scholar who lived in the West as the center of the earth at the time. Second, these two people brought or at least triggered Islam and Christianity into their respective fundamentalisms because their thoughts are based on exclusivity. This article concludes that Barth and Banna have similarities and differences in addressing the issue of Morality that lead toward religious fundamentalism in Christianity and Islam.

\section{B. Morality and Religious Fundamentalism}

People employ the concept of morality and fundamentalism in the religious discourse of values and norms. Morality in Hobbes' perspective is "primarily concerned with the behavior of people insofar as that behavior affects others; it prohibits the kind of conduct that harms others and encourages the kind of conduct that helps them."3 Morality in this sense prevents people to prey on others because the nature of human being is to conduct good deed on other fellow beings, not only human beings. Morality is part of the innate of the human being because, in the perspective of religions, God creates human with knowledge (logos). The narrative of natural morality helps the human being to be naturally moral animals. ${ }^{4}$ In social life, religious values curve the innate goodness in human being by which people always put moral judgment as of the pattern of social relationships.

${ }^{3}$ Bernard Gert, Morality: It's Nature and Justification (Oxford: Oxford University Press, 2005), 9.

${ }^{4}$ Richard Joyce, The Evolution of Morality (Cambridge, MA: The MIT Press, 2007), 3.

JURNAL THEOLOGIA — Volume 29, Nomor 2, Desember 2018 
Moral judgment is the guidance for personal and communal behavior that serves as a maxim to consider bad and good deed. In Immanuel Kant' concept, moral judgment guides people to conduct practical imperative to respect the life of other human beings. Kant claims, "an action done from duty does not have its moral worth in the purpose which is to be achieved through it but in the maxim whereby it is determined."5 In this argument, the good deed is not a result of inclination but a moral duty. Kant believes that respect to the law including sacred law is the "vital principle of all morality." 6 Moral judgment in this sense is moral imperative as the code of conduct. Moral judgment is moral inescapability that functions as categorical imperative in Kant' perspective of morality. ${ }^{7}$ Through moral judgment, people develop mutual relationships with others as a moral imperative because of vulnerability. By acknowledging the vulnerability of human being, people must employ moral judgment to protect and respect others and vice versa.

As the pattern of protecting and respecting others in social relationships, the concept of morality conveys group norms and values. Thiroux and Krasemann state that morality applies to three categories: individual, religious and social morality. Individual morality refers to individual relationships to oneself an individual to other beings based on the social or religious code of conduct. While religious morality insinuates the relationship of an individual with supra natural being. Religious morality is based on sacred scripture that serves as a maxim in a particular religious community. Social morality means the relationship of an individual to others in a social context based on social consensus in a given milieu. ${ }^{8}$ Therefore, morality covers inner relationship, social interaction, and spiritual rapport.

Considering its inner, social and spiritual rapports, morality has its exclusivity that might lead to the claim of social norms. For instance, it was through Nazi Morality that people of Germany in the Hitler era preyed other

${ }^{5}$ Immanuel Kant, Foundations of the Metaphysics of Moral, translated by Lewis W Beck, 2 ed. (New Jersey: Prentice-Hall, Inc, 1997), 16.

${ }^{6}$ Immanuel Kant, Critique of Practical Reason, Introduction by Dennis Sweet (New York: Barnes \& Noble Books, 2004), 74. 2003).

${ }^{7}$ Immanuel Kant, Critique of Pure Reason, translated by Norman K. Smith (New York: Palgrave,

8Jacques P. Thiroux and Keith W. Krasemann, Ethics: Theory and Practice (New Jersey: Pearson Prentice Hall, 2007), 11-2. 
people: Jew and Gipsy. The massacre of others starts from a certain standard of morality that belongs to particular groups. In this context, Nazi morality becomes moral judgment for people of German to claim that certain groups of human deserve to be harmed. The same case applies to Eric Rudolph a Christian, who attack an abortion clinic in Birmingham, Alabama in 1998 and Timothy McVeigh who associates his Christian identity with militia culture that forced him to attack Oklahoma City Federal building in 1995 killed 168 people. ${ }^{9}$ It's true that ISIS group also claims that the killing of people in Iraq has moral judgment that based on their own interpretation of religious teaching. The instances here highlight that universal norms and global morality might guide people to common humanity: respect and protect others. However, moral judgment based on human selfishness might lead to the act fundamentalism: killing the body of others or attacking the faith of other groups.

Fundamentalism has been a hot topic in our today world after the advent of 9/11 that followed by islamophobia in many parts of the Western world. ${ }^{10}$ The concept of religious fundamentalism comes out from evangelical Christian in America called Moral Majority or Christian Right. The main argument of the fundamentalist Christian is to maintain Christian tradition that rooted in the Bible. The doctrine of the second coming of Jesus has produced the rise of Christian fundamentalism in Western countries, especially the United States of America. Christian terrorist attacks by Rudolph and McVeigh emphasize the relationship of the doctrine with fundamentalism for both of them believed that the actions will fulfill the promise of the second coming of Jesus..$^{11}$ In this sense, the movement such as What Would Jesus Do (WWJD) comes into being in order to bring, according to the Moral Majority group, good morality to American society.12 Currently, the concept also applies to other fundamentalist movements in many religions. Hindus Fundamentalism in India explains that religious fundamentalism lies in any religious group, not only Abrahamic religions. Aleaz'

${ }^{9}$ Mark Juergensmeyer, Terror in the Mind of God: The Global Rise of Religious Violence (Berkeley: The University of California Press, 2000), 30-4.

${ }^{10}$ Sindre Bangstad, "Islamophobia: What's in a Name? Analysing the Discourses of Stopp Islamiseringen av Norge (Stop the Islamisation of Norway, SIAN)," Journal of Muslims in Europe 5 (2016): 145-69, https://doi.org/10.1163/22117954-12341324.

${ }^{11}$ Juergensmeyer, Terror in the Mind of God, 133-4.

${ }^{12}$ Harvey Cox, Religion in the Secular City (New York: Simon \& Schuste, 1984); Stephen Carter, God's Name in Vain: The Wrongs and Rights of Religion in Politics (New York: Basic Book Publisher, 2001).

JURNAL THEOLOGIA — Volume 29, Nomor 2, Desember 2018 
research discovers that Hindu fundamentalism in India has already come into being since 1870. The group named Sangh Parivar claims "the glorious future based on a golden past."13 Through this political idea, the Bharatiya Janata Party (BJP) captured political gain in India while promoting exclusivity and intolerance. In the case of Muslim fundamentalism, groups such as Al Qaeda and ISIS who have linked the two movements with group interpretation of Islamic teachings. ${ }^{14}$ The fundamentalist groups' interpretation of Islamic teaching is different from that of Muslim groups that perceive other religious groups as the fellow seeking of God truth, not as enemies and competitors.

Fundamentalism is a pattern of belief and behavior (rather than a specific ideology or set of doctrines) shared by some secular as well as religious groups and individuals..$^{15}$ In general, fundamentalism has social and religious faces. Frank Lechner argues that fundamentalism is simply an antimodern movement. ${ }^{16}$ At the same tune, Benjamin Barber insists that parochial hatreds and ethnicity toward global commerce and universal markets might develop group fundamentalism. ${ }^{17}$ Fundamentalism in this sense is the rejection of any idea of modernity in the global context because modernity might destroy existing values of a given group. Scholars such as Bassam Tibi and Gabriel Almond believe that fundamentalism has a strong connection with religious values and struggles. Tibi argues that fundamentalism is the indication of the clash of civilizations: the clash between the Muslim World and the West. Fundamentalism in the Muslim world has political implication to reject the idea of Westernization and to create a sense of the Islamic community (ummah) or universal Islamic community.18 Supporting Tibi's argumentation, Almond argues that "religious fundamentalism refers to a discernible pattern of religious militancy by which self-styled "true believers" attempt to arrest the erosion of

${ }^{13}$ K. P. Aleaz, "The Challenge of The Sangh Parivar in Doing Theology in India," Journal of Theologies and Cultures in Asia 3 (2004): 57 - 79.

${ }^{14}$ Juergensmeyer, Terror in the Mind of God, 183.

${ }^{15}$ Gabriel A. Almond, R. Scott Appleby, and Emmanuel Sivan, Strong Religion: The Rise of Fundamentalism around the World (The Fundamantalism Project) (Chicago: The University of Chicago Press, 2003).

${ }^{16}$ Frank J. Lechner, "Global Fundamentalism," in A Future of Religions?, ed. William H. Swatos (New York: Sage Publication, 1993), 27-32.

${ }^{17 B e n j a m i n ~ B a r b e r, ~ J i h a d ~ v s . ~ M c W o r l d ~(N e w ~ Y o r k: ~ T i m e s ~ B o o k s, ~ 1995), ~ 17-20 . ~}$

${ }^{18}$ Bassam Tibi, The Challenge of Fundamentalism: Political Islam and the New World Disorder (Berkeley: The University of California Press, 1998). 
religious identity, fortify the borders of the religious community, and create viable alternatives to secular institutions and behaviors." ${ }^{19}$ Religious fundamentalism in this context reflects the idea of religious revivalism in the context of world secularism. Religious fundamentalist groups always associate the movements with "authority of sacred past." 20

\section{Barth's Dogmatics and The Theology of Ethics}

The Church Dogmatics gives a strong impression that Barth was a moralist. Here, Barth argues dogmatics as ethics for a Christian. A Christian who lives according to the teaching of Jesus Christ, the Word of God's teaching, he proclaimed the foundation of the Christian life as an ethical system. ${ }^{21} \mathrm{He}$ had been raised as a moralist and also trained in the liberal theology of so-called "ethical Christianity." According to Barth, morality is a fundamental requirement of religion. At this point, religion without morality is unworkable and the separation between religion and morality is unthinkable. ${ }^{22}$ In this moralistic mindset, any ethical malfunction means a total failure of religion, since the essence of Christianity as a religion is ethics as a doctrine of God. At this juncture, any ethical failure is considered disobedience to the God whose doctrine has been revealed to the earth in His only Son, Jesus Christ. ${ }^{23}$

Barth was very concerned with the present reality of Christian salvation and believed that it should be proved in Christian ethics. For Barth, Christian ethics is a consequence of a Christian being elected by God through Jesus Christ. Jesus Christ is the central point of Christian ethics, that is, Jesus is the Word of God whose life and teaching bear the divine command. Indeed, the divine command is the focal point of the covenant between God and human beings. Barth insists Jesus Christ is the center of the covenant. It seems to me that all of Barth's theology of ethics falls upon Jesus Christ as the Word of God whose teaching is the main doctrine of God. He says:

\footnotetext{
${ }^{19}$ Almond, Appleby, and Sivan, Strong Religion, 17.

${ }^{20}$ Almond, Appleby, and Sivan, 92.

${ }^{21}$ Karl Barth, Church Dogmatics Volume I.2 The Doctrine of the Word of God, ed. G.W. Bromiley (New York: T\&T Clark, 2009), 42.

${ }^{22}$ Barth, 45.

${ }^{23}$ Karl Barth, Church Dogmatics Volume II.2 The Doctrine of God, ed. G. W. Bromiley (New York: T\&T Clark, 2009), 4.
}

JURNAL THEOLOGIA — Volume 29, Nomor 2, Desember 2018 
Jesus, who fulfills the command of God, does not give the answer, but by God's grace, He is the answer to the ethical question put by God's grace. The sanctification of man, the fact that he is claimed by God, the fulfillment of his predetermination in his self-determination to obedience, the judgment of God on man and His command to him in its actual concrete fulfillmentthey all take place here in Jesus Christ.24

Here Immanuel Kant's Categorical Imperative contributes an indispensable part in Barth's theology of ethics. The Categorical Imperative, as commanding a deed as objectively compulsory without making any reference to an end in view, ${ }^{25}$ is in Barth's theology of ethics centered around Jesus Christ as a necessary action for any Christian. In volume one of the Church Dogmatics, we see this whenever he talks about salvation. Whether reconciliation, sanctification, Christian life, or ethics, Barth's starting point is always the sovereignty of God and His reconciliation of the world through Jesus Christ the Son and the Word of God. Even though the human being is pietistic by nature, trying to sanctify itself by inserting something else by its own labors, in Barth's perspective the human being ought to go back to the point of departure, to the freedom one has in the Word of God. For Barth, the Word of God is real Christian as well as Church's proclamation. ${ }^{26}$

The most crucial point in Barth's ethical theology is that "the Word of God is moral truth. It means only the doer of the Word hears the Word of God. God's Word is given for us to hear and act responsibly. The Word of God is God's positive command which motivates human beings to live in accordance with its absolutely superior Divine power. Because God has been existing on the earth and in the life of human beings since the presentation of Jesus Christ to the earth, the command should be present and work in any means and circumstances. ${ }^{27}$ Therefore, dogmatics and ethics are inseparable in the unity of the sanctifying Word of God. In fact, the theme of dogmatics is simply the Word of God. According to Barth, "good" means being sanctified by God, and to be sanctified or made holy means to be related to God. In short, the Christian ethical norm of the good should be sharply differentiated from a humanistic definition of moral

${ }^{24}$ Barth, 9.

${ }^{25}$ Kant, Foundations of the Metaphysics of Moral, 31.

26Karl Barth, Church Dogmatics Volume I.1 The Doctrine of the Word of God, ed. G. W. Bromiley (New York: T\&T Clark, 2009), 91.

27Barth, 87. 
goodness. The question of goodness can be answered only by reference to the one who alone is good and also the one who commands, God himself.

\section{The Command of God as Social Value}

In the theology of Barth, the starting point of theological ethics is "the command of the grace of God and his distinctive doctrine of the divine order is grounded upon the congenial election of God. When he states that "election is the sun, the sanctification is its shine, who is to separate the two?" it means the origin of our sanctification is the divine election before our existence.

In this context, the command of God is the means of sanctification, since it is the sanctifying command: "The first thing that theological ethics has to show and to develop as a basic and all-comprehensive truth, is the fact and extent that... command of God is an event. This is the specific ethical-dogmatic task as it now confronts us within the framework of the doctrine of God." ${ }^{28}$ Barth understands the command of God as the basic values for human life, at least a good Christian life. In his view, the command of God becomes the law that curves human social and spiritual life.

God does not give His command to anybody, but only to whom God is gracious. Here the grace of God is the commanding grace. It is not simply because God is powerful, but because God has given us Himself in Jesus Christ. Thus the divine basis and right for the claim upon us exist in Jesus Christ. Here the motif of sola gratia is crucial in every way.

The command of God is given to us to respond properly to His gracious election. At this point, the action is good insofar as it is a response proper to the divine grace and therefore its good consists in its responsibility.

It is the grace of God which is attested to us by the claim of God. The grace of God wills and creates the covenant between God and man. It, therefore, determines man to exist in this covenant. It determines him to be the partner of God. It, therefore, determines his action to correspondence, conformity, uniformity with God's action. ... the covenant of grace alone constitutes the real relationship between God and man. Man is determined only to be the partner of the gracious God. ${ }^{29}$

28Barth, Church Dogmatics Volume II.2, 548

${ }^{29}$ Barth, 575-576. 
Barth radically annulled the possibility of general or philosophical ethics and strongly advocated the need for special or theological ethics due to the fundamental difference of the ethical norm. General ethics forms part of the doctrine of God as a counterpart to the doctrine of election. Thus general ethics has to show: 1) How the command is the claim made by God upon man in the full significance and power of His sovereign grace, i.e., the demand that man approves the merciful action of God in His own action, freely and cheerfully accepting it. 2) That the command, as it claims man, is always God's decision: His decision about the right or wrong of human action: His sovereign and eternal decision, which as such has already been made, but is now as always made again and will always continue to be so. 3) That the command, as it claims the man and decides concerning him, is God's judgment upon him; the judgment of His grace by which man is at once condemned and acquitted and thus becomes free for eternal life. This freeing man for eternal life by God's judging grace is the final goal, the real work and therefore the original purpose of the command of God. It is man's sanctification. Good human action is action set free by the command of God. $^{30}$

On the other hand, special ethics in the perspective of Barth is sometimes taken to mean the understanding of the Divine's command as a given text, partly written and partly unwritten, which is made up of the Biblical text in which there is believed to be seen universally binding divine ordinances and directions. The Divine command of certain propositions is assumed to be universally legitimate, along with the natural moral law generally discernible to human reason, and finally, the particular norms which have been handed down historically in the tradition of Western Christianity and which lay claim to universal validity. ${ }^{31}$

At this level, God's command has been used and perceived as a legal text. As a legal text, the Biblical text is taken literally as it was written down and plays the role of the lawful manuscript for the ethical teachers and to whom it ought to instruct. The task of special ethics is: 1) In expounding the statements of this law - on the analogy of country law -in relation to the plenitude of conditions and possibilities in which human action takes place. 2) In doing or making a regulation or issuing a prohibition, commandment or permission in respect of future action. If the moralist knows the command of God on the one side, i.e., the

${ }^{30}$ Barth, Church Dogmatics Volume I.2, 6

31Barth, 7. 
definition of universal moral law in the form of such a text, and the sphere or various spheres of real human action on the other, then basically in every case in which the conscience might be in doubt he is able to tell himself and others what is to be chosen as good or rejected as evil. ${ }^{32}$

One might argue that, on the one hand, allgemeine ethik, as upward look, concerns the relationship with God and His freeing of man for eternal life by the divine grace of command and judgment. On the other hand, spezielle ethik looks down and inquires with respect to sanctification as it comes to man from God, the subjective side of the same event, what becomes of him in consequence, that is man's real activity. Since he has already founded his general ethics in the doctrine of God, Barth here presents his special ethics in the doctrine of creation in Church Dogmatics III. It is essential because the command of God does not hang ineffectively in the air above man, being forced to follow its movement and thus being led automatically to man and his real activity which is always concrete, particular and special." ${ }^{\text {33 }}$

To sum up, Barth's fundamentalism is based upon Jesus Christ as the Word of God. As the focal point of Christian morality, Jesus Christ is the covenant between God and human beings. Thus, to keep the covenant a Christian without any means should obey Jesus Christ's teaching. Here we encounter Sola Christus as the groundwork of the Christian life. In short, the fundamentalism of Barth is to stick to Jesus Christ's teaching as the moral basis for conducting interactions between human beings and God as well as the fellow living beings. Christian fundamentalism is more or less an invitation to follow Jesus Christ as a right path and the Word of God.

\section{E. Hasan al-Banna's Moral Community}

Hasan al-Banna was born in Ismailiyah, Egypt in the colonial era. Here AlBanna encountered what Frantz Fanon says is the zone of non-being. ${ }^{34}$ It was the situation when the British colonial power dominated the whole life system of Egypt and the Egyptians, as the colonized, were required to follow what the master ordered. At the time, colonialism was a legitimate action against other

\footnotetext{
${ }^{32}$ Barth, 7-8

33Barth, 8-9

${ }^{34}$ Frantz Fanon, The Wretched of the Earth (New York: Grove Press, 1963), 41.
}

JURNAL THEOLOGIA — Volume 29, Nomor 2, Desember 2018 
countries because of the civilized and uncivilized image. The Westerners believed that people in Asia and Africa were less civilized than those of Europe, therefore controlling over the uncivilized was a legal action according to international law.

The British Empire controlled the life of Egyptians by violence and coercion because it had the greatest naval power during the colonial era. In addition, besides violence and coercion, the British power also conducted ideological cooptation through the school system and brought the British, Western, Christian lifestyle and social norms onto Egyptian soil. ${ }^{35}$ By borrowing the concept of hegemony from Antonio Gramsci, ${ }^{36}$ one can say that Banna lived under a hegemony by the colonial and Western civilization. ${ }^{37}$ This is the starting point for why Banna came up with the concept of the ummah -Muslim society- and Islamic morality.

Banna's concept of morality and the sanctification of the Islamic society was based on his hatred and enmity against the British colonialism. Muslim society in Egypt should distinguish its identity and lifestyle from that of the WesternChristian life.

As a consequence of living in the colonial era, Banna employed Islamic teaching to fight against British colonialism. The idea behind Banna's movement was to save Islam from the impact of British colonialism and Western values on Muslim society in Egypt.

Disillusioned by the apathy of the Islamic establishment, which he saw as failing to defend Islam from the secular and materialistic influence that was sweeping Egypt, Banna started to preach in coffee shops, small mosques, schools, and anywhere else he and his early followers could find an audience. ${ }^{38}$

35John L. Esposito, Islam and Politics (New York: Syracuse University Press, 1984), 51.

${ }^{36}$ Antonio Gramsci insisted hegemony is a control by the people who have capital over the lay people through violence, coercion and ideology. The ideology is a control over people by the common sense and what people believe as the truth-the false truth. See: Q. Hoare and G. N. Smith, ed, Selection of the Prison Notebooks Antonio Gramsci (New York: International Publishers, 1971), 208.

${ }^{37}$ Isa Blumi, Chaos in Yemen: Societal Collapse and the New Authoritarianism (London and New York: Routledge, 2011), 21.

${ }^{38}$ Lorenzo Vidino, The New Muslim Brotherhood in the West (New York: Columbia University Press, 2010), 18. 
Lorenzo Vidino's study on the Muslim Brotherhood shows a strong enmity and hatred toward Western colonialism across Egypt and other Muslim worlds. In Banna's mind, according to Vidino, blind imitation of Western colonial values as a paradigm as well as lifestyle introduced poisons that weakened Egyptian Muslims in particular and the Muslim world in general. ${ }^{39}$ As with his counterpart Mawdudi in Pakistan, the movement's inspiration came from nationalism as well as socialist movements, along with other ideologies from the West. Yet, both Banna and al-Mawdudi had based the Muslim Brotherhood and Jamaat al-Islami organizations on Islamic teaching and lifestyle. Consequently, the Qur'ân and the Prophet Muhammad's sayings, Hadìth, have been the pivotal foundation in both Islamic movements. ${ }^{40}$

Nevertheless, even though Banna rejected colonialism and the Western lifestyle, he believed that modernity could still bring advantages to the Muslim community. Yet his ideas on modernity were different than those of Western secularization. ${ }^{41}$ Acceptable modernity according to Banna is inspired by Islam's glorious history where Muslims could compete with the West. In fact, the Muslim Brotherhood is the first Islamic organization that attempted simultaneously to modernize and re-Islamize the Islamic world.

In the mind of Banna, Islam is a complete religion -al-dìn al-shāmil. Islam covers the whole of life from the household to the political system. Therefore, when a Muslim is looking for a moral foundation, the Qur'ān and Hadìth of the Prophet are the foremost sources of the morality of Islamic society. ${ }^{42}$ Islam is the answer to the moral problem that Egypt encountered during the colonial period. In fact, according to Banna, the total implementation of sharia would restore the life of the Muslims who were humiliated by the Western powers under colonialism.43

39Vidino.

${ }^{40}$ A. A. Mawdudi, Toward Understanding Islam (Islamabad: Islamic Publication, 1947), 38-9.

${ }^{41}$ Gudrun Kramer, Makers of the Muslim World: Hasan al-Banna (Oxford: Oneworld Publication, 2010), 42.

${ }^{42}$ Hasan al-Banna, The Friday Sermon of the Martyr (Cairo: Dār al-Tawzi' wa 'l-Nashr alIslāmiyyah, 2005).

${ }^{43}$ R. Hrair Dekmejian, Islam in Revolution: Fundamentalism in the Arab World (New York: Syracuse University Press, 1995), 74-5.

JURNAL THEOLOGIA — Volume 29, Nomor 2, Desember 2018 
Furthermore, Islamic sharia is the foundation for the ummah -communitylife. As an ideology, sharia is the teaching -'aqidah- which is needed for the moral standard of society. Here, sharia also functions as the jurisdiction -fiqh- to judge what is lawful -ḥalāl-and unlawful -ḥarām- for the Islamic society. In this context, Sharia itself is narrowly understood as fiqh. Therefore, Banna insists sharia is the good counsel for Islamic people because it also restores human dignity by implementing good conduct and avoiding the wrongdoing -amr bi 'lma'rüf nahi munkar. The concept of right conduct and human dignity based on Islamic teaching is the focal point of Banna's coffee shop preaching that he did on Tuesdays from one coffee shop to another in Cairo during the colonial period. ${ }^{44}$

Regarding Islamic sharia, the structure of Islamic law has situated Qur'ān in the highest place. Qur'ān is the Word of God that was revealed to the Prophet Muhammad as it is. Qur'ān, like the Talmud and the Bible, was divulged to human beings from the mother of the scripture -Ummu al-Kitāb- which is the only Word and Command of God. After the Qur'ān, the Hadith, or the sayings of the Prophet Muhammad, is the second basis for Islamic moral standards. Yet, a Hadìth which is functioning as sharia should be a strong Hadīth -al-ahādith alșāhihiah, a Hadìth agreed on by the companions of the Prophet -tābi'inn- as well as the wives -Aisha- who listen directly to the Prophet when he mentioned the Hadìth. $^{45}$

In addition to the Qur'ān and Hadìth, the moral standard of Islam is the right conduct of the Prophet Muhammad -al Sunna. According to Islamic teaching, the Prophet Muhammad is a perfect human being -al-insān al-kāmil - whose deeds as well as sayings are the right path for any Muslim. Regarding the Prophet Muhammad's perfect human being, Banna's counterpart Mawdudi says:

He was the one whose example and teachings inspired the thought of oneness of mankind, equality of the human race, true democracy, and real freedom into the world.... He is the only example where all the excellences are blended together into one personality. He is a philosopher and a seer and also a living example of what he teaches. He is a legislator and also the teacher of morals. He is a spiritual luminary as well as a religious guide. His

${ }^{44}$ Hasan al-Banna, The Saying of Hasan al-Banna, the Leader (Cairo: Maktabah al-Qur'ān, 1985), 2003), 44-5.

45Seyyed Hossein Nasr, Islam: Religion, History and Civilization (New York: HarperCollins, 
vision penetrates every aspect of life and there is nothing which he touches and does not adorn. ${ }^{46}$

As with Mawdudi, Banna considered Islam an identity rather than religion. This identity would fall into a different line if one compared it to that of Western civilization since the Muslim identity is the perfect self as the legacy from the perfect human being, the Prophet Muhammad. ${ }^{47}$ Regarding this difference that Banna conveys in his teaching, Lawrence Davidson concludes: "He (Banna) associated British worldview with the qualities of radical individualism, gender equality, class conflict, materialism, and atheism.... Islamic tradition and view are duty of piety, altruism, community fellowship, strong family orientation, domestic role of women, and social justice."48

\section{F. Islamic Sharia and Moral Society}

The only way to rejuvenate an Islamic society by creating a moral society based on Islamic sharia is through the Islamic state. In so doing, Banna believes that the creation of a new generation of believers could invigorate the Muslim community free from any foreign domination. ${ }^{49}$ By having an Islamic State, Banna argued that the whole Islamic teaching and worldview could be implemented. Banna's struggle for an Islamic state can be clarified if one puts it into dialogue with Hegel's theory of spirit. In Hegel's perspective, the reason is the spirit, when its certainty of being all reality has been raised to the level of truth, and the reason is consciously aware of itself as its own world, and the world as itself.50 Banna's reason for an Islamic state is rooted in the spirit that Islamic sharia is a complete jurisdiction that God has given to the human being through the Prophet. The spirit has been elevated into the level of truth where sharia is being perceived as the moral truth. Consequently, sharia as the truth needs its space or world to meet its fundamental function within Muslim society.

\footnotetext{
46Mawdudi, Toward Understanding Islam, 52-3.

${ }^{47}$ Kramer, Makers of the Muslim World, 93.

${ }^{48}$ Lawrence Davidson, Islamic Fundamentalism: An Introduction (London: Greenwood Press, 2003), 21.

${ }^{49}$ Marion Boulby, ed., The Muslim Brotherhood and the Kings of Jordan 1945-1993 (Atlanta: Scholar Press, 1999), 43.

${ }^{50}$ G. W. F. Hegel, The Phenomenology of Mind (New York: Dover Publications, 2003), 251.
} 
Moreover, Ikhwān al-Muslimīn, or Muslim Brotherhood, the organization that Banna established, should lead to the Islamic state for a Muslim society which is the realization of Islamic sharia. As in Hegel's theory of the state, the state is the realized ethical idea or ethical spirit. It is the will which manifests itself, makes itself clear and visible, substantiates itself,51 Banna understood the Islamic state as the realization of sharia as an ethical idea or Islam as the spirit and way of life. Here is the integral part of Islam which is the integration of religion and state: since Islam is the spirit of morality which should be implemented in the state law or general will for Muslim society. ${ }^{52}$

The implementation of morality according to Islamic sharia in the political sense required an Islamic state that has power over the Muslims and nonMuslims -al-dhimmy. At this point, it seems like Banna has learned from Hobbes' Leviathan, ${ }^{53}$ where the state protects and defends Islamic values and lifestyle from any Western infiltration and the damage of Muslim morality. The Islamic state, here, conveys the sovereignty which gives life and motion to the whole body of Muslim society where reward and punishment are based on the sharia.

Lastly, in the mind of Banna, the rule of Islam is comprehensive teaching that organizes Islamic members in this world and in the next life. As comprehensive teaching, the foundation of Islam is the book of Almighty God and the Hadith and/or Sunna of His Messenger. In fact, Islam as a universal faith is a general will for all Muslims across the globe, regardless of their race and color. ${ }^{54}$ There is no doubt that the Banna's whole concept of morality in Islam is centered around the Qur'ān as a Word of Almighty God.

In a nutshell, Banna's concept of morality began from a political debate with European, Christian civilization. In developing his argument, Banna placed the Qur'ān and Hadìth as the political sources where Muslim society could find both moral guidance and political protection. Hence, one might conclude that Banna's fundamentalism is more or less a political concept since for Banna the main

${ }^{51}$ G. W. F. Hegel, Philosophy of Right (New York: Dover Publications, 2005), 132.

${ }^{52}$ Kramer, Makers of the Muslim World, 114.

53Thomas Hobbes, Leviathan: With Selected Variants from Latin Edition of 1668, ed. Edwin Curley (Indianapolis: Hackett Publishing Company, 1994), 3-4.

${ }^{54}$ John Obert Voll, Islam: Continuity and Change in the Modern World (New York: Syracuse University Press, 1994), 181. 
struggle of Islam is to restore Islamic society through the real implementation of sharia as the moral foundation by establishing an Islamic state.

\section{G. Barth-Banna' Similarities and Differences}

Karl Barth and Hasan al-Banna shares some similarities and differences in their movements. First, both Barth and Banna employing Sacred Past: scriptural arguments and religious traditions for their social movements. Unlike Martin Heidegger who supported "Nazi government in advancing the view that Germany's mission was to disclose Dasein to Europe and the world," based on scriptural morality Barth boldly refused Hitler concept of uber alles that forced the regime to massacre millions of Jews in Europe. Barth places Israel as the chosen people as the center of his political theology by which Barth rejecting Nazi idea of special human being/nation. As a consequence, "Barth would preach that salvation comes from the Jews and would battle the German Christians' denial of the Old Testament and the Jewishness of Jesus Christ." Bart believes in the scriptural texts of Jewish presence and the concept of salvation in Christian teaching. Taking this perspective, Barth publicly rejected Hitler claim of the Jewish role in world disorder.

Using the same perspective, Banna opposed British colonial government idea to employ materialism and rationalism in shaping Egyptian worldview. Banna perceived British colonial power as "greedy capitalism and godless communism."55 In his perspective, the government that based on mundane foundation brings nothing, but social destruction. Therefore, Banna proposed religious value-based politics that rooted in faithful conviction. Banna insists that government is an integral part of religious practices by which the government ensuring the total implementation of religious values using formal political mechanism. He argues that the government should be based on three pillars: "responsibility of ruler before God and the umma; the unity of the umma; and the consultation of its will (shūrā')."56

Both Banna and Barth have insisted that politics of state finds it's ground in the sacred texts and religious traditions because the government, in their perspectives, functions as tools to serve the community and the will of the

55Soage, "Hasan al-Bannā and Sayyid Quțb: Continuity or Rupture?” 296.

56 Soage, 301.

JURNAL THEOLOGIA - Volume 29, Nomor 2, Desember 2018 
Ultimate Reality. Unlike Barth who propose the scriptural basis for political life, but could not urge for a physical Christian state, Banna insisted that a religiousbased state would guarantee the total implementation of religious values and traditions. In Banna's mind, an Islamic state is "an alternate system -socially, politically, economically, and culturally- that can challenge western civilization." ${ }^{57}$ Although both Banna and Barth argued for a spiritual-scriptural foundation of the state, the main differences lie between them is the state of the system.

Second, both scholars building the concept of morality based on the religious code of conduct. Religious authority becomes a maxim for moral judgments in Barth and Banna concepts of morality. Moral judgment becomes a milestone for personal and communal behavior. Barth and Banna believe that religious values and good practices contribute to the formation of the perfect society. In his Seminal, Church Dogmatics, Barth labeled this kind of communal moral judgment as to ethical Christianity. Taking the same tune, Banna underlined that moral judgment that based on Islamic teachings would create an Islamic Identity or al-fikrah al-islāmiyyah. ${ }^{58}$

Third, Barth and Banna function as activists who fighting the hegemonic power using the interpretation of sacred texts and employing religious languages to influence the followers as well as fellow citizens. Barth argued against nationalism for the state-nationalism is a new-atheism. He believed that strong nationalism may move German-Christians from religious faith because the state, especially in Hitler's era, required total submission of its citizens to government policy. ${ }^{59}$ Hitler through the Social Nationalist Party (NSDAP) imposed the concept of the fatherland (vaterland) and Deutsch uber alles as the means of political hegemony and weapon of ethnic cleansing against Jewish in Europe. Rejecting Hitler Social Nationalist Party hegemony, Barth joined the opposition party (SPD) to fight Hitler idea theologically. ${ }^{60}$ Using the same token, Banna established Ikhwān al-Muslimin to fight British hegemony over Arab land, people and religion. Banna employed the solidarity of Jama'a that rooted in

\footnotetext{
57al-Anani, "The Power of the Jama'a," 47.

58al-Anani, 48.

${ }^{59}$ Moseley, Nations and Nationalism, 9.

${ }^{60}$ Moseley, 107.
} 
religious texts (Qur'ān and Sunna) as the main foundation of the Muslim Brotherhood to unite Muslim to resist British hegemony. ${ }^{61}$

Forth, both Barth and Banna have inspired religious fundamentalism in their own faith traditions. Barth's idea of morality based on religious teaching has influenced Christian fundamentalist movements across the globe. Underlining pneumatology (understanding of the Holy Spirit), Barth has influenced Evangelical churches that faith to Christ is the center of Christian salvation (heil). Barth believed that through the spirit that human being experience reconciliation (versohnung) with God. ${ }^{62}$ Barth concept of salvation impacted group such as Moral Majority in the United States who has politically emphasized Christian morality to American society. However, Barth has not pushed for the establishment of a Christian country. Rather, he underlined the centrality of Christian morality in state policy. Although Barth and Banna forced the total implementation of the religious values to society, unlike Barth, Banna underlined the urgency of Islamic State existence to guarantee the total implementation of Islamic value. ${ }^{63}$

\section{H. Conclusion}

Both Barth and Banna have been the central figures of religious fundamentalism in Protestant Christianity and Islam. The two scholars focused on the implementation of religious morality in society as part of the religious mission to reform a corrupted community. Barth rejecting his own nation, German, ultranationalism in Hitler time that crooked Christian morality. Banna preached and established the total implementation of Qur'ān and Sunna to fight the corruption of Islamic values during British colonialism in Arab countries. Although both scholars and religious leaders shared many similarities, they have different goals in the practical argument on the relationships of religion and politics. Barth, on the one hand, argued for the implementation of Christian teachings in politics without requiring the existence of the religious political system. On the other

\footnotetext{
${ }^{61}$ Khalil al-Anani, Inside the Muslim Brotherhood: Religion, Identity, and Politics (Oxford: Oxford University Press, 2016), 51.

${ }^{62}$ Trevor Hart, "Revelation," in The Cambridge Companion to Karl Barth, ed. John Webster (Cambridge: CambridgeUniversity Press, 2000), 54.

63Wickham, The Muslim Brotherhood: The Evolution of an Islamist Movement, 276.
}

JURNAL THEOLOGIA — Volume 29, Nomor 2, Desember 2018 
hand, Banna believes that only through religious based political system or religious state that Islamic morality and value could be implemented.

Barth focused his thought on social justice when he was a student under Adolf von Harnack. His theology used to focus on God and the brotherhoodsisterhood of human beings. Yet, his struggle on the colonial context and the militaristic movement in Germany and the concern of parish issues shifted his focus more on Jesus Christ as the Word of God. Jesus Christ as the Word of God and the covenant of God and human being is the only way humans could be sanctified. The sanctification is a result of obedience by being the hearers and the doers of God's Word. The doers and the hearers, as a consequence, live a moral life based on the obedience of the Word of God. This theology could lead to fundamentalism since it triggers a Christian to be an exclusive person who restricts salvation only as of the consequence of morality within the church and by Jesus Christ alone. So, Barth's morality and fundamentalism are much more about personal or congregational piety. As one of the biggest names in Christian discourse, Barth's morality and fundamentalism also influence some Christian denominations in Indonesia whose mission is to invite people into Christianity by embracing Jesus Christ alone.

Unlike Barth, Hasan al-Banna's fundamentalism and morality are the pursuit of social justice and political power. His fundamentalism is the longing for the Islamic state by which Islamic sharia could be implemented within a Muslim society. At this juncture, the implementation of sharia will protect the Muslim community from moral degradation because of the influence of Western civilization and values. Indeed, the moral standard in Islam is based on Qur'ān as the Word of God and the Hadith as the sayings of the Prophet Muhammad. Here, morality in Islamic society, based on God's Word, is different than that of the West which rests upon the human mind and individualism. Banna's idea leads to fundamentalism in Islam which is to struggle to perform the Islamic state. Thus, Banna's fundamentalism is much more on political issues and community. Banna's ideas influence modernist Islam in Indonesia which works for an Islamic state in Indonesia. Indonesia Muslim Brotherhood, or Jamaat Tarbiyah, which puts great effort into its political party -the Prosperous Justice Partyaims to Islamize Indonesia and at the end to shift Indonesia from a nationalistic based state to an Islamic state. 


\section{Acknowledgement}

The author is grateful for critics and insights from Professor Bill O'Neill of the Jesuit School of Santa Clara University, California, and Professor Munir Jiwa of the Graduate Theological Union, California. These professors help the author to comprehend the idea of ethics and fundamentalisms in Christianity and Islam begin with pivotal scholars such as Karl Barth and Hassan al-Banna.[]

\section{BIBLIOGRAPHY}

Aboul-Enein, Youssef H. "Al-Ikhwan al-Muslimeen: The Muslim Brotherhood." Military Review 83, no. 4 (2003): 26-31. https://www.questia.com/ library/journal/1G1-109268859/al-ikhwan-al-muslimeen-the-muslimbrotherhood.

al-Anani, Khalil. "The Power of the Jama'a: The Role of Hasan al-Banna in Constructing the Muslim Brotherhood's Collective Identity." Sociology of Islam 1, no. 1-2 (2013): 41-63. https://doi.org/10.1163/2213141800101003.

Al-Anani, Khalil. Inside the Muslim Brotherhood: Religion, Identity, and Politics. Oxford: Oxford University Press, 2016.

Al-Banna, Hasan. The Friday Sermon of the Martyr. Cairo: Dār al-Tawzi' wa 'lNashr al-Islāmiyyah, 2005.

-_- The Saying of Hasan al-Banna, the Leader. Cairo: Maktabah al-Qur'ān, 1985.

Aleaz, K. P. "The Challenge of The Sangh Parivar in Doing Theology in India." Journal of Theologies and Cultures in Asia 3 (2004): 57 - 79.

Almond, Gabriel A., R. Scott Appleby, and Emmanuel Sivan. Strong Religion: The Rise of Fundamentalism around the World (The Fundamentalism Project). Chicago: The University of Chicago Press, 2003.

Bangstad, Sindre. "Islamophobia: What's in a Name? Analyzing the Discourses of Stopp Islamiseringen Av Norge (Stop The Islamisation of Norway, SIAN)." Journal of Muslims in Europe 5 (2016): 145-69. https://doi.org/10.1163/ 22117954-12341324.

JURNAL THEOLOGIA — Volume 29, Nomor 2, Desember 2018 
Barber, Benjamin. Jihad vs. McWorld. New York: Times Books, 1995.

Barth, Karl. Church Dogmatics Volume I.1 The Doctrine of the Word of God. Edited by G. W. Bromiley. New York: T\&T Clark, 2009.

- - C. Church Dogmatics Volume I.2 The Doctrine of the Word of God. Ed. G.W. Bromiley. New York: T\&T Clark, 2009.

- _ C Church Dogmatics Volume II.2 The Doctrine of God. Ed. G. W. Bromiley. New York: T\&T Clark, 2009.

Blumi, Isa. Chaos in Yemen: Societal Collapse and the New Authoritarianism. London and New York: Routledge, 2011.

Boulby, Marion, ed. The Muslim Brotherhood and the Kings of Jordan 1945-1993. Atlanta: Scholar Press, 1999.

Carter, Stephen. God's Name in Vain: The Wrongs and Rights of Religion in Politics. New York: Basic Book Publisher, 2001.

Coutts, Jon. A Shared Mercy: Karl Barth on Forgiveness and the Church. Grove: IVP Academic, 2016.

Cox, Harvey. Religion in the Secular City. New York: Simon \& Schuster, 1984.

Davidson, Lawrence. Islamic Fundamentalism: An Introduction. London: Greenwood Press, 2003.

Dekmejian, R. Hrair. Islam in Revolution: Fundamentalism in the Arab World. New York: Syracuse University Press, 1995.

Esposito, John L. Islam and Politics. New York: Syracuse University Press, 1984.

Euben, Roxanne L., and Muhammad Qasim Zaman, eds. Princeton Readings in Islamic Thought: Texts and Contexts from al-Banna to Bin Laden. Princeton: Princeton University Press, 2009.

Fanon, Frantz. The Wretched of the Earth. New York: Grove Press, 1963.

Gert, Bernard. Morality: It's Nature and Justification. Oxford: Oxford University Press, 2005.

Hart, Trevor. "Revelation." In The Cambridge Companion to Karl Barth. Ed. John Webster. Cambridge: CambridgeUniversity Press, 2000.

Hegel, G. W. F. Philosophy of Right. New York: Dover Publications, 2005. 
———. The Phenomenology of Mind. New York: Dover Publications, 2003.

Hoare, Q., and G. N. Smith, eds. Selection of the Prison Notebooks Antonio Gramsci. New York: International Publishers, 1971.

Hobbes, Thomas. Leviathan: With Selected Variants from Latin Edition of 1668. Ed. Edwin Curley. Indianapolis: Hackett Publishing Company, 1994.

Joyce, Richard. The Evolution of Morality. Cambridge, MA: The MIT Press, 2007.

Juergensmeyer, Mark. Terror in the Mind of God: The Global Rise of Religious Violence. Berkeley: The University of California Press, 2000.

Kant, Immanuel. Critique of Practical Reason. Edited by Dennis Sweet. New York: Barnes \& Noble Books, 2004.

_- C Critique of Pure Reason. Translated by Norman K. Smith. New York: Palgrave, 2003.

- _ . Foundations of the Metaphysics of Moral. Translated by Lewis W Beck. 2nd ed. New Jersey: Prentice-Hall, Inc, 1997.

Kramer, Gudrun. Makers of the Muslim World: Hasan al-Banna. Oxford: Oneworld Publication, 2010.

Lechner, Frank J. "Global Fundamentalism." In A Future of Religions?, edited by William H. Swatos. New York: Sage Publication, 1993.

Massmann, Alexander. Citizenship in Heaven and on Earth: Karl Barth's Ethics. Minneapolis: Fortress, 2015.

Mawdudi, A. A. Toward Understanding Islam. Islamabad: Islamic Publication, 1947.

Moseley, Carys. Nations and Nationalism in the Theology of Karl Barth. Oxford: Oxford University Press, 2013.

Nasr, Seyyed Hossein. Islam: Religion, History and Civilization. New York: HarperCollins, 2003.

Ramadan, Tariq. Aux Sources Du Renoveau Musulman: D' al-Afghani a Hasan alBanna Un Siecle de Reformisme Islamique (Religions En Dialogue). Paris: Centurion, 1998. 
Soage, Ana. "Ḥasan al-Bannā and Sayyid Quṭb: Continuity or Rupture?" The Muslim World 99, no. 2 (2009): 294-311. https://doi.org/10.1111/j.14781913.2009.01270.x.

Thiroux, Jacques P., and Keith W. Krasemann. Ethics: Theory and Practice. New Jersey: Pearson Prentice Hall, 2007.

Tibi, Bassam. The Challenge of Fundamentalism: Political Islam and the New World Disorder. Berkeley: The University of California Press, 1998.

Vidino, Lorenzo. The New Muslim Brotherhood in the West. New York: Columbia University Press, 2010.

Voll, John Obert. Islam: Continuity and Change in the Modern World. New York: Syracuse University Press, 1994.

Webster, John. Barth's Earlier Theology. New York: T\&T Clark, 2005.

- - - ed. The Cambridge Companion to Karl Barth. Cambridge: Cambridge University Press, 2000.

Werpehowski, William. Karl Barth and Christian Ethics: Living in Truth. Burlington: Ashgate, 2014.

Wickham, Carrie R. The Muslim Brotherhood: The Evolution of an Islamist Movement. Princeton: Princeton University Press, 2013. 